\title{
Evaluation of the effects of the infusion of Ocimum selloi leaves using the Allium cepa model
}

\author{
Maria do Socorro Mascarenhas Santos', Maria Helena Verdan², Raul Cremonezi Piva², \\ Lucilene Finoto Viana ${ }^{2}$, Claudia Andrea Lima Cardoso ${ }^{1}$ \\ ${ }^{1}$ Universidade Estadual de Mato Grosso do Sul, Dourados, Mato Grosso do Sul, Brasil. E-mail: maria_mascarenhas@outlook.com, \\ claudiacardosouems1@gmail.com \\ ${ }^{2}$ Universidade Federal da Grande Dourados, Dourados, Mato Grosso do Sul, Brasil. E-mail: mhelenaverdan@gmail.com, \\ raul.c.piva@hotmail.com, lucilenefinoto@hotmail.com
}

Received: 14/11/2020; Accepted: 12/02/2021.

\begin{abstract}
Ocimum selloi is a plant used in traditional medicine as a tea; however, no studies have reported the biological activity of the aqueous extract of this plant. This study aimed to evaluate the cytotoxicity, genotoxicity, and mutagenicity of two concentrations of an aqueous extract prepared by infusion of leaves from $O$. selloi using the Allium cepa model. The $O$. selloi infusion contained $107.1 \pm 1.27 \mathrm{mg} \mathrm{GAE} \mathrm{g}^{-1}$. In the A. cepa test, the concentration of the extract influenced the germination index; for $1.0 \mathrm{mg} \mathrm{mL}^{-1}$, it was $60.78 \%$ and for $5.0 \mathrm{mg} \mathrm{mL}^{-1}$, it was $51.14 \%$. The evaluation of root development also showed differences between the two concentrations and the negative control, and differences in mitotic index were observed between the concentrations and the negative control; the concentration of $1.0 \mathrm{mg} \mathrm{mL}^{-1}$ showed an index of $4.1 \%$, and for $5.0 \mathrm{mg} \mathrm{mL}^{-1}$ it was $3.7 \%$. An index of chromosomal changes of $0.1 \%$ was observed for a concentration of $5.0 \mathrm{mg} \mathrm{mL}^{-1}$. The A. cepa test therefore showed that the studied concentrations did not cause deformations in cells, cell death or mutagenic alterations.
\end{abstract}

Keywords: Genotoxicity, Mitotic index, Cell death.

\section{Avaliação dos efeitos da infusão das folhas de Ocimum selloi usando o modelo de Allium cepa}

\section{RESUMO}

O Ocimum selloi é uma planta utilizada na medicina popular na forma de chá, no entanto, nenhum estudo relata a ação biológica do extrato aquoso desta planta. Este estudo teve como objetivo avaliar a citotoxicidade, genotoxicidade e mutagenicidade em duas concentrações de um extrato aquoso preparado por infusão das folhas de $O$. selloi utilizando o modelo do Allium cepa. A infusão de $O$. selloi continha 107,1 $\pm 1,27 \mathrm{mg}$ AGE g-1. No teste de A. серa, a concentração do extrato influenciou no índice de germinação; para $1,0 \mathrm{mg} \mathrm{mL}^{-1}$, foi $60,78 \%$ e para $5,0 \mathrm{mg} \mathrm{mL}^{-1}$, foi $51,14 \%$. A avaliação do desenvolvimento radicular também mostrou diferenças entre as duas concentrações e o controle negativo, e diferenças no índice mitótico foram observadas entre as concentrações e o controle negativo; a concentração de $1,0 \mathrm{mg} \mathrm{mL}^{-1}$ apresentou índice de 4,1\% e para 5,0 mg mL $\mathrm{mL}^{-1}$ foi de $3,7 \%$. Um índice de alterações cromossômicas de $0,1 \%$ foi observado para a concentração de 5,0 mg mL $\mathrm{mL}^{-1} \mathrm{O}$ teste de $A$. cepa, portanto, mostrou que as concentrações estudadas não causaram deformações nas células, morte celular ou alterações mutagênicas.

Palavras-chave: Genotoxicidade, Índice mitótico, Morte celular. 
Natural products have traditionally attracted attention mainly in the context of medicinal herbal products, and the consumption of natural products by people seeking a healthier lifestyle has been growing year by year. Additionally, medicinal plants have been widely used for many purposes, including in therapies, cosmetics, food, condiments, and as raw materials for herbal medicines (Dar et al., 2017). Species of the Lamiaceae family have a long history of use as culinary spices and in folk medicine because they are rich in bioactive substances, including the plants belonging to genus Ocimum, which has commercial importance (Padalia et al., 2013).

The Ocimum genus comprises plants that contain large amounts of antioxidant compounds such as vitamin C, vitamin E, flavonoids, and carotenoids (Henrique et al., 2017) and are important sources of essential oils (Santos et al., 2016). Essential oils from the Ocimum genus, popularly known as basil, are used in various processes in the pharmaceutical, cosmetic and food industries, and stand out for their unique aroma and for containing metabolites that can be chemically and biologically explored (Rewers and Jedrzejczyk, 2016).

For most plant species, especially medicinal ones, the allelopathic effect predominates when leaf extracts are employed (Rosado et al., 2009). In the Ocimum genus, studies have been centered on essential oils, as they demonstrate important biological activities (Martins et al., 2010; Pandey et al., 2014), and have been used traditionally to treat different diseases (Sajjadi, 2006).

The aqueous extract of the leaves of $O$. gratissimum was investigated by Olamilosoye et al. (2018) to treat acetic acid-induced colitis in male rats. The extract was administered orally at doses of 200 and $400 \mathrm{mg} \mathrm{kg}^{-1}$ per day for 20 consecutive days, and a decrease in the effects caused by induced colitis was observed.

Meanwhile, Chaudhary et al. (2016) analyzed the antihyperglycemic influence of the aqueous extract of the seeds of $O$. basilicum in rats with streptozotocin-induced diabetes, and its effect on biochemical parameters, serum electrolyte level, hematological indexes, and body weight at doses of 250 and $500 \mathrm{mg} \mathrm{kg}^{-1}$. Treatment with $O$. basilicum extract reduced the glucose level in rats at both dosage levels, and there were improvements in body weight and in other parameters analyzed, showing that this extract can be used to treat diabetes mellitus II and associated complications.

Zangeneh et al. (2019) studied the aqueous extract of the leaves from $O$. basilicum and its potential healing properties with regards to skin wounds. Twenty male rats were treated with an ointment prepared with $3 \%$ aqueous extract, and the healing of a cutaneous wound was periodically evaluated. The authors concluded that ointment based on $O$. basilicum extract has wound healing properties, since its administration increased the levels of skin wound contracture.
The plant investigated in this study is $O$. selloi, has been used in traditional medicine as a tea, mainly to treat digestive diseases, intestinal gases, and diarrhea (Campos Mota and Flores Sánchez, 2013). Some studies have reported the properties of the essential oil from this plant, including as an analgesic (França et al., 2008). However, studies focusing on aqueous extracts are still scarce with the species of this genus, and $O$. selloi in particular has no description in the literature.

Costa et al. (2015) evaluated the in vitro effect of the essential oil of leaves and flowers of $O$. selloi on the growth of mycelia and on the germination of spores of Alternaria alternata, Colletotrichum gloeosporioides, and Moniliophthora perniciosa. They evaluated concentrations of $125,250,500$, and $1000 \mu \mathrm{g} \mathrm{mL} \mathrm{m}^{-1}$, and the data showed that the essential oil, when applied at a concentration of $1000 \mu \mathrm{g} \mathrm{mL} \mathrm{m}^{-1}$, has inhibitory activity against both mycelial growth and spore germination.

In this sense, cytotoxic, mutagenic, and genotoxic tests are of great importance, especially when they are fast and low cost, such as the Allium cepa model (Rodrigues et al., 2016). The A. cepa test is considered efficient for analyzing and monitoring the possible genotoxic changes that certain substances may cause; they are evaluated for cell proliferation, mitotic index, and the presence of aberrations or chromosomal changes (Frescura et al., 2013; Silva et al., 2015; Terceiro and Oliveira, 2020). It has been used in studies related to the analysis of bioactive substances of plant origin (Aragão et al., 2017; Alves et al., 2018) to identify potential risks or benefits of using these plants.

Mutagenic effects may occur and are analyzed through nuclear changes (Özkara et al., 2015; Santos Filho et al., 2019). This study aimed to determine total phenolic content and evaluate the cytotoxic, genotoxic, and mutagenic action of two concentrations of the aqueous extract of the leaves of $O$. selloi using the $A$. cepa model.

\section{Plant material}

Leaves of $O$. selloi were collected from the Horto de Plantas Medicinais of the Federal University of Grande Dourados (UFGD) with an exsiccate deposited at the herbarium under the number 5689 and registered in SISGEN as A055721.

The aqueous extract was obtained using fresh leaves of $O$. selloi at $10 \%$ (vegetable mass and water volume). The leaves were collected and promptly packed in sterile packaging. The fresh leaves were crushed (3-5 $\mathrm{mm}$ ) and the extracts obtained by infusion in water heated to $98 \pm$ $2^{\circ} \mathrm{C}$ and kept in a closed container. The extract remained in direct contact with the leaves for $30 \mathrm{~min}$ until it reached room temperature $\left(23 \pm 2^{\circ} \mathrm{C}\right)$. Then, it was filtered and lyophilized (Cristo, Alpha 1-2 LD Plus). This process was carried out in triplicate. 


\section{Total Phenolic Content}

The total phenolic content was determined using Folin-Ciocalteu's reagent as described by Djeridane et al. (2006). The infusion (100 $\left.\mu \mathrm{L}, 1 \mathrm{mg} \mathrm{FM} \mathrm{mL} \mathrm{m}^{-1}\right)$ was added to $1 \mathrm{~mL}$ of ultrapure water and $500 \mu \mathrm{L}$ of FolinCiocalteu reagent $(1: 10 \mathrm{v} / \mathrm{v})$ in water. After $1 \mathrm{~min}, 1.5$ $\mathrm{mL}$ of $\mathrm{Na}_{2} \mathrm{CO}_{3}$ solution $(20 \% \mathrm{w} / \mathrm{v})$ was added. The final mixture was incubated in dark for $2 \mathrm{~h}$ and the absorbance was determined by spectrophotometry (FEMTO 700 PLUS) $(\lambda=760 \mathrm{~nm})$. Gallic acid (GA) was used as a standard to construct a curve, and the result was expressed in mg of gallic acid equivalent (GAE) per $g$ of lyophilized extract. The analyses were performed in triplicate.

\section{Allium cepa}

Samples of the lyophilized extract from the leaves of $O$. selloi were prepared at concentrations of $1.0 \mathrm{mg} \mathrm{mL}^{-1}$ and $5.0 \mathrm{mg} \mathrm{mL}^{-1}$ by dilution with distilled water. Distilled water and trifluralin at $0.84 \mu \mathrm{g} \mathrm{mL}^{-1}$ were used as positive control and negative control, respectively. The seeds (30 units - Isla brand), free of pesticides, were placed in Petri dishes and $3 \mathrm{~mL}$ of the relevant sample was added. They were then incubated for $96 \mathrm{~h}$ at $23 \pm 3{ }^{\circ} \mathrm{C}$ in a biochemical oxygen demand incubator, a procedure adapted from Leme and Marin-Morales (2009). The germinated seeds (primary root emission) were counted manually, and the root size was measured with the aid of a caliper (Digmess). Then, the seeds were transferred to Falcon tubes and soaked with Carnoy fixative solution (absolute ethanol/acetic acid 3:1), where they remained for $6 \mathrm{~h}$ at $25^{\circ} \mathrm{C}$. Carnoy was again applied to samples, which were then stored at $-20{ }^{\circ} \mathrm{C}$. The seeds were washed with distilled water and subjected to hydrolysis with $1 \mathrm{~mol} \mathrm{~L}$ ${ }^{1}$ hydrochloric acid at $60{ }^{\circ} \mathrm{C}$ for 8 to $11 \mathrm{~min}$. After they were washed again, Schiffe's reagent was added, and the samples were placed in dark for $2 \mathrm{~h}$ (Castro et al., 2020). Slides were prepared with the meristems of the roots from $A$. серa exposed to the samples, and the readings were performed using a Nikon microscope (Eclipse, E200) at 400x magnification. Each sample was composed of 10 slides resulting in 5000 cells. The calculations were performed according to Francisco et al. (2018), and presented as germination index (GI\%), root size (RS nm), mitotic index (MI\%), mutagenicity index (MTI\%), cell death index (CDI\%), and chromosomal alteration index (CAI\%). They were performed in triplicate. The results were analyzed with Microsoft Excel 2016 with ActionStat supplementation. Tukey's test was performed with a significance level of 0.05 ( $\mathrm{p}<$ 0.05).

The aqueous extract of leaves from $O$. selloi showed differences in relation to the GI\% between the different concentrations of the extract and the negative control ( $p$ $<0.05)$ and also in relation to the positive control ( $\mathrm{p}<$ 0.05). Notably, there was also a reduction in the germination index when the extract concentration increased from $1.0 \mathrm{mg} \mathrm{mL}^{-1}$ (GI $60.78 \%$ ) to $5.0 \mathrm{mg} \mathrm{mL}^{-1}$ (GI 51.14\%) (Table 1). Therefore, extract composition is seen to disrupt the germination of A. cepa seeds according to varying concentration, with germination index decreasing as the concentration increases. Regarding the evaluation of root development (RS), there were significant differences between both the concentrations of the extract and the negative $(\mathrm{p}<0.05)$ and positive $(\mathrm{p}<0.05)$ controls.

These data are in agreement with the findings of other studies in the literature. Borooah (2011) investigated the cytotoxic and genotoxic effects of leaf extract from $O$. gratissimum on meristematic cells of roots from $A$. cepa, using concentrations of $1,2.5,5,10$, and $20 \%\left(\mathrm{v} \mathrm{v}^{-1}\right)$. The data showed that all tested concentrations except $1 \%$ inhibited root growth compared to the control. A study by Sousa et al. (2018), in which the cytotoxic and genotoxic effects of the aqueous extract of leaves and stems of Costus spiralis (Jacq.) Roscoe were evaluated using $A$. cepa $\left(18,9\right.$, and $\left.4.5 \mathrm{mg} \mathrm{mL}^{-1}\right)$, showed that the extracts inhibited the growth of $A$. cepa root depending on the concentration of the extract, with the lowest concentration showing the least inhibition and the most concentrated dose the greatest inhibition. Castro et al. (2020) evaluated the action of infusion of leaves of Campomanesia sessiliflora using A. cepa, and observed that there was a reduction in the germination index and a reduction in the size of the roots at the highest concentrations of the extract.

Plants biosynthesize several metabolites that have defined protective functions and can present themselves as allelopathic substances (Rocha et al., 2018). Our results could have been influenced by the total phenolic content of the sample, which was $107.1 \pm 1.27 \mathrm{mg} \mathrm{GAE}$ $\mathrm{g}^{-1}$.

Table 1. Germination index, root size, mitotic index, mutagenicity index and cell death index of the extract $O$. selloi leaves in A. cepa.

\begin{tabular}{ccccccc} 
Extract & GI $(\%)$ & RS $(\mathbf{n m})$ & MI $(\%)$ & MTI $(\%)$ & CDI (\%) & CAI (\%) \\
\hline $1.0 \mathrm{mg} \mathrm{mL}^{-1}$ & $60.78 \pm 2.16 \mathrm{~b}$ & $4.29 \pm 0.51 \mathrm{~b}$ & $4.1 \pm 0.3 \mathrm{~b}$ & - & - & \\
$5.0 \mathrm{mg} \mathrm{mL}^{-1}$ & $51.14 \pm 1.44 \mathrm{c}$ & $3.65 \pm 0.43 \mathrm{c}$ & $3.7 \pm 0.4 \mathrm{c}$ & - & - & $0.1 \pm 0.1 \mathrm{~b}$ \\
$\mathrm{NC}$ & $89.81 \pm 3.37 \mathrm{a}$ & $4.92 \pm 1.17 \mathrm{a}$ & $5.7 \pm 0.4 \mathrm{a}$ & - & - & \\
PC & $41.98 \pm 1.12 \mathrm{~d}$ & $2.72 \pm 0.63 \mathrm{~d}$ & $0.5 \pm 0.1 \mathrm{~d}$ & $3.9 \pm 0.2 \mathrm{a}$ & $2.6 \pm 0.1 \mathrm{a}$ & $9.2 \pm 0.3 \mathrm{a}$ \\
\hline
\end{tabular}

Source: Authors. GI (germination index); RS (Root size); MI (mitotic index); MTI (mutagenicity index); CDI (cell death index); NC (negative control, distilled water was used); PC (positive control, $0.84 \mu \mathrm{g} \mathrm{mL}{ }^{-1}$ trifluralin was used); CAI (Chromosomal Alteration Index); Values expressed as mean \pm standard deviation. 
The concentration of phenolic compounds, according to Rufino et al. (2010), can be classified as low if it is up to $100 \mathrm{mg} \mathrm{g}^{-1}$, average from $100 \mathrm{mg} \mathrm{g}^{-1}$ to $500 \mathrm{mg} \mathrm{g}^{-1}$, and high when it has a concentration greater than $500 \mathrm{mg} \mathrm{g}^{-1}$, therefore, the concentration in the $O$. selloi extract can be classified as average. Phenolic substances can interfere with germination and root development, reducing their size. Aslam et al. (2017), Cheema et al. (2012), and Sousa et al. (2018) have suggested that depending on the concentration of the extract and its composition, these substances may influence the root growth of A. cepa.

In the evaluation of the MI, significant differences were observed between concentrations of the extract and the negative control $(\mathrm{p}<0.05)$, with values of $4.1 \%$ for $1.0 \mathrm{mg} \mathrm{mL}^{-1}$ and $3.7 \%$ for $5.0 \mathrm{mg} \mathrm{mL}^{-1}$, compared with $5.7 \%$ for the negative control. The positive control MI value was $0.5 \%$, as shown in Table 1 . This result may be explained by the phenolic substances present in the sample (Table 1).

According to Leme and Marin-Morales (2009), MI can be used as a parameter to assess the cytotoxicity of a variety of substances. Thus, cytotoxicity tests are essential for characterizing the intrinsic ability of substances to cause metabolic alteration in cells (Aragão et al., 2017). The aqueous extract from $O$. selloi exerts a cytotoxic effect on A. cepa seeds, and as the concentration of extract increases, it is more cytotoxic, although not in a dose-dependent manner. However, the concentrations used in this study did not cause deformations in the cells, so the MTI was zero, and the same was true for the CDI.

In a study by Manimozhi (2016), the effect of the extract obtained from the fresh leaves of Ocimum sanctum L. was evaluated using $A$. cepa at different concentrations $(0.5,1.0,1.5,2.0,2.5,3.0,3.5$, and $4.0 \%)$. There was a decrease in MI with an increase in the extract concentration, and the author inferred that the application of the extracts of fresh $O$. sanctum leaves may have a cytotoxic effect on the meristematic tissues of $A$. cepa.

For the CAI, the concentration of $5.0 \mathrm{mg} \mathrm{mL}^{-1}$ showed an index of $0.1 \%$, while no changes were observed for the $1.0 \mathrm{mg} \mathrm{mL}^{-1}$ concentration or for the negative control (Table 1). Analysis of CAI indicates damage caused to cells because of exposure to toxic agents (Bagatini et al., 2007).

The A. cepa test provides a quick analysis, since the occurrence of chromosomal changes can be observed during the phases of cell division, and is considered an indicator of mutagenic action caused by elements and agents that can both disrupt chromosomes and cause their loss, according to Santos Filho et al. (2019).

The aqueous extract of $O$. selloi leaves showed an average phenolic compound content. The A. cepa test showed that the concentrations of the extract did not cause deformations in the cells, resulting in the absence of mutagenicity and cell death; low chromosomal alterations in percentage terms only at the highest concentration, suggest that, in the studied concentrations, the extract did not show cytotoxic action.

\section{Authors' Contribution}

Maria do Socorro Mascarenhas Santos: design and execution of the experiments, analysis of data, writting the original draft; Maria Helena Verdan: execution of the experiments, analysis of the data, writting the draft; Raul Cremonezi Piva: execution of the experiments; Lucilene Finoto Viana: analysis of the data; Claudia Andrea Lima Cardoso: support of infrastructure, discussion of data, analysis of the data, revision of the manuscript.

\section{Acknowledgments}

Fundação de Apoio ao Desenvolvimento do Ensino, Ciência e Tecnologia do Estado de Mato Grosso do Sul (FUNDECT); Conselho Nacional de Desenvolvimento Científico e Tecnológico (CNPq) (311975/2018-6 CALC); Programa Institucional de Bolsas aos Alunos de Pós-Graduação (PIBAP-UEMS); Coordenação de Aperfeiçoamento de Pessoal de Nível Superior (CAPES).

\section{Bibliographic References}

Alves, T.A. Pinheiro, P.F., Praça-Fontes, M.M., AndradeVieira, L.F., Corrêa, K.B., Alves, T.A., Cruz, F.A., Lacerda Júnior, V., Ferreira, A., Soares, T.C.B. 2018. Toxicity of thymol, carvacrol and their respective phenoxy acetic acids in Lactuca sativa and Sorghum bicolor. Industrial Crops and $\begin{array}{llll}\text { Products, } & 114, & 59-67 . & \text { DOI: }\end{array}$ https://doi.org/10.1016/j.indcrop.2018.01.071.

Aragão, F.B., Queiroz, V.T., Ferreira, A., Costa, A.V., Pinheiro, P.F., Carrijo, T.T., Andrade-Vieira, L.F. 2017. Phytotoxicity and cytotoxicity of Lepidaploa rufogrisea (Asteraceae) extracts in the plant model Lactuca sativa (Asteraceae). Revista de Biologia Tropical, 65(2), 435-443. DOI: http://dx.doi.org/10.15517/rbt.v65i2.25696.

Aslam, F., Khaliq, A., Matloob, A., Tanveer, A., Hussain, S., Zahir, Z.A. 2017. Allelopathy in Agro-Ecosystems: A Critical Review of Wheat Allelopathy-Concepts and Implications. Chemoecology, 27, 1-24. http://dx.doi.org/10.15517/rbt.v65i2.25696.

Bagatini, M.D., Silva, A.C.F., Tedesco, S.B. 2007. Uso do sistema teste de Allium cepa como bioindicador de genotoxicidade de infusões de plantas medicinais. Revista Brasileira de Farmacognosia, 17(3), 444-447. DOI: https://doi.org/10.1590/S0102-695X2007000300019.

Borooah, D.D. 2011. Genotoxicity assessment of water extract of Ocimum gratissimum L. using the Allium cepa assay. International Journal of Plant, Animal and Environmental Science, 1(2), 185-188.

Campos Mota, L., Flores Sánchez, D. 2013. Sustratos orgánicos como alternativa para la producción de albahaca (Ocimum 
selloi Benth). Revista Mexicana de Ciências Agrícolas, 4(5), 1055-1061. DOI: https://doi.org/10.29312/remexca.v0i5.1311.

Castro, T.L.A., Viana, L.F., Santos, M.S.M., Cardoso, C.A.L. 2020. Ação antiproliferativa e mutagenicidade da infusão das folhas de Campomanesia sessiliflora no modelo de Allium cepa. Research, Society and Development, 9(7), e625974555. DOI: https://doi.org/10.33448/rsd-v9i7.4555.

Chaudhary, S., Semwal, A., Kumar, H., Verma, H.C., Kumar, A. 2016. In-vivo study for anti-hyperglycemic potential of aqueous extract of Basil seeds (Ocimum basilicum Linn) and its influence on biochemical parameters, serum electrolytes and haematological indices. Biomedicine \& Pharmacotherapy, 84, 2008-2013.DOI: https://doi.org/10.1016/j.biopha.2016.11.020.

Cheema, Z.A., Farooq, M., Wahid, A. 2012. Allelopathy: current trends and future applications. Springer Science \& Business Media.

Costa, L.C.B., Pinto, J.E.B.P., Bertolucci, S.K.V., Costa, J.D.B., Alves, P.B., Niculau, E.D.S. 2015. Atividade antifúngica in vitro do óleo essencial de Ocimum selloi e metilchavicol contra fungos fitopatogênicos. [In vitro antifungal activity of Ocimum selloi essential oil and methylchavicol against phytopathogenic fungi]. Revista Ciência Agronômica, 46(2), 428-435. DOI: http://dx.doi.org/10.5935/1806-6690.20150023.

Dar, R.A., Shahnawaz, M., Qazi, P.H. 2017. General overview of medicinal plants: A review. The Journal of Phytopharmacology, 6(6), 349-351.

Djeridane, A., Yousfi, M., Nadjemi, B., Boutassouna, D., Stocker, P., Vidal, N. 2006. Antioxidant activity of some algerian medicinal plants extracts containing phenolic compounds. Food Chemistry, 97(1), 654-660. DOI: https://doi.org/10.1016/j.foodchem.2005.04.028.

França, C.S., Menezes, F.S., Costa, L.C., Niculau, E.S., Alves, P.B., Pinto, J.E., Marçal, R.M. 2008. Analgesic and antidiarrheal properties of Ocimum selloi essential oil in mice. $\begin{array}{lll}\text { Fitoterapia, } & 79(8), & 569-573 .\end{array}$ https://doi.org/10.1016/j.fitote.2008.06.002.

Francisco, L.F.V., Crispim, B.D.A., Viana, L.F., Nascimento, H.D.S., Raposo Junior, J.L., Grisolia, A.B. 2018. Cytotoxicity, genotoxicity and mutagenicity of aluminum, manganese and lead in meristematic cells of root Allium cepa. Orbital: The Electronic Journal of Chemistry, 10(1), 60-65. DOI: http://dx.doi.org/10.17807/orbital.v10i1.1037.

Frescura, V.D.S., Kuhn, A.W., Laughinghouse IV, H.D., Paranhos, J.T., Tedesco, S.B. 2013. Post-treatment with plant extracts used in Brazilian folk medicine caused a partial reversal of the antiproliferative effect of glyphosate in the Allium cepa test. Biocell, 37(2), 23-28. DOI: 10.32604/biocell.2013.37.023.

Henrique, V.A., Ferreira, L.P., Reis Nunes, C. 2017. Análise físico-química e antioxidante de manjericão (Ocimum basilicum L.) orgânico. Revista Interdisciplinar Pensamento Científico, 3(2), 85-97. DOI: http://dx.doi.org/10.20951/24466778/v3n2a6.

Leme, D.M., Marin-Morales, M.A. 2009. Allium cepa test in environmental monitoring: a review on its application. Mutation Research/Reviews in Mutation Research, 682(1), 7181. DOI: https://doi.org/10.1016/j.mrrev.2009.06.002.
Manimozhi, V. 2016. Effect of fresh leaf extracts of Ocimum sanctum Linn. On the somatic chromosomes of Allium cepa Linn. In: Proc. XV AZRA International Conference Recent Advances in Life Sciences, Ethiraj College for Women, Chennai, 197-200.

Martins, A.G.L.A., Nascimento, A.R., Mouchrek Filho, J.E., Mendes Filho, N.E., Souza, A.G., Aragão, N.E., Silva, D.S.V.D. 2010. Atividade antibacteriana do óleo essencial do manjericão frente a sorogrupos de Escherichia coli enteropatogênica isolados de alfaces. Ciência Rural, 40(8), 1791-1796. DOI: http://dx.doi.org/10.1590/S010384782010005000127.

Olamilosoye, K.P., Akomolafe, R.O., Akinsomisoye, O.S., Adefisayo, M.A., Alabi, Q.K. 2018. The aqueous extract of Ocimum gratissimum leaves ameliorates acetic acid-induced colitis via improving antioxidant status and hematological parameters in male Wistar rats. Egyptian Journal of Basic and Applied Sciences, 5(3), 220-227. DOI: https://doi.org/10.1016/j.ejbas.2018.05.006.

Özkara, A., Akyıl, D., Eren, Y., Erdoğmuş, S.F. 2015. Potential cytotoxic effect of Anilofos by using Allium cepa assay. Cytotechnology, 67(5), 783-791. DOI: https://doi.org/10.1007/s10616-014-9716-1.

Padalia, R.C., Verma, R.S., Chauhan, A., Chanotiya, C.S. 2013. Changes in aroma profiles of 11 Indian Ocimum taxa during plant ontogeny. Acta Physiologiae Plantarum, 35(8), 25672587. DOI: https://doi.org/10.1007/s11738-013-1293-y.

Pandey, A.K., Singh, P., Tripathi, N.N. 2014. Chemistry and bioactivities of essential oils of some Ocimum species: an overview. Asian Pacific Journal of Tropical Biomedicine, 4(9), 682-694. DOI: https://doi.org/10.12980/APJTB.4.2014C77.

Rewers, M., Jedrzejczyk, I. 2016. Genetic characterization of Ocimum genus using flow cytometry and inter-simple sequence repeat markers. Industrial Crops and Products, 91, 142-151. DOI: https://doi.org/10.1016/j.indcrop.2016.07.006.

Rocha, V.D., Santos, T.A., Bispo, R.B., Zortéa, K.É.M., Rossi, A.A.B. 2018. Efeito alelopático de extratos aquosos de Solanum paniculatum L., na germinação e crescimento inicial de alface. Revista de Ciências Agroambientais, 16(1), 72-79. DOI: https://doi.org/10.5327/rcaa.v16i1.1805.

Rodrigues, G.Z.P, Dalzochio, T., Gehlen, G. 2016. Uso do bioensaio com Allium cepa L. e análises físico-químicas e microbiológicas para avaliação da qualidade do Rio da Ilha, RS, Brasil. Acta Toxicológica Argentina, 24(2), 101-108.

Rosado, L.D.S., Rodrigues, H.C.A., Pinto, J.E.B.P., Custódio, T.N., Pinto, L.B.B., Bertolucci, S.K.V. 2009. Alelopatia do extrato aquoso e do óleo essencial de folhas do manjericão "Maria Bonita" na germinação de alface, tomate e melissa. Revista Brasileira de Plantas Medicinais, 11(4), 422-428. DOI: http://dx.doi.org/10.1590/S1516-05722009000400010.

Rufino, M.S.M, Alves, R.E., Brito, E.S., Pérez-Jiménez, J., Saura-Calixto, F., Mancini-Filho, J. 2010. Bioactive compounds and antioxidant capacities of 18 non-traditional tropical fruits from Brazil. Food Chemistry, 121(4), 996-1002. DOI: https://doi.org/10.1016/j.foodchem.2010.01.037.

Sajjadi, S.E. 2006. Analysis of the essential oils of two cultivated basil (Ocimum basilicum L.) from Iran. DARU Journal of Pharmaceutical Sciences, 14(3), 128-130. 
Santos Filho, R.D., Vicari, T., Santos, S.A., Felisbino, K., Mattoso, N., Sant'Anna-Santos, B.F., Cestari, M.M., Leme, D.M. 2019. Genotoxicity of titanium dioxide nanoparticles and triggering of defense mechanisms in Allium cepa. Genetics and Molecular Biology, 42(2), 425-435. DOI: https://doi.org/10.1590/1678-4685-gmb-2018-0205.

Santos, M.S., Santos Souza, L.E., Costa, C.A.S., Gomes, F.P., Bomfim Costa, L.C., Oliveira, R.A., Costa Silva, D. 2016. Effects of water deficit on morphophysiology, productivity and chemical composition of Ocimum africanum Lour (Lamiaceae). African Journal of Agricultural Research, 11(21), 1924-1934. DOI: https://doi.org/10.5897/AJAR2015.10248.

Silva, A.E.P., Moura, J.W.M., Neto, M.P.L. 2015. Avaliação tóxica, citotóxica, genotóxica e mutagênica Daturnera ulmifolia L.(chanana) em células eucarióticas. Saúde em Foco, 2(1), 25-48.
Sousa, W.C., Paz, A.T.S, Rocha, J.D., Conceição, E.C., Almeida, L.M., Chen, L.C., Borges L.L., Bailão, E.F. 2018. In vivo assessment of cyto/genotoxic, antigenotoxic and antifungal potential of Costus spiralis (Jacq.) Roscoe leaves and stems. Anais da Academia Brasileira de Ciências, 90(2), 15651577. DOI: https://doi.org/10.1590/0001-3765201720170714.

Terceiro, A.J.M.D., Oliveira, M.A.S. 2020. Avaliação da toxicidade, citotoxicidade, genotoxicidade e mutagenicidade do infuso das folhas de Lippia sidoides (Verbenaceae). Revista Ciência e Estudos Acadêmicos de Medicina, 1(12), 71-82.

Zangeneh, M.M., Zangeneh, A., Seydi, N., Moradi, R. 2019. Evaluation of cutaneous wound healing activity of Ocimum basilicum aqueous extract ointment in rats. Comparative Clinical Pathology, 28(5), 1447-1454. DOI: https://doi.org/10.1007/s00580-019-02988-x. 